\title{
Impact of early intensified postoperative corticosteroids on immune reaction rates after Descemet membrane endothelial keratoplasty (DMEK)
}

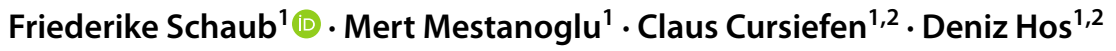

Received: 6 July 2021 / Revised: 16 August 2021 / Accepted: 23 August 2021 / Published online: 1 September 2021

(C) The Author(s) 2021, corrected publication 2022

\section{Key messages}

- Immune reactions (IR) are the main reason for graft failure after Descemet membrane endothelial keratoplasty (DMEK).

- Eyes developed an IR during the first two postoperative years.

- A trend towards less IRs in the hourly group is noted, however the difference was statistically not significant.

\section{Dear Editor,}

Immune reactions (IR) are the main reason for graft failure after keratoplasty. The risk of developing an IR after "Descemet membrane endothelial keratoplasty" (DMEK) is considerably low $[1,2]$, and we have previously shown that the IR rates after DMEK are about $1 \%$ at 1 and $2 \%$ at 4 years postoperatively $[3,4]$. Factors/events that increase the IR risk after DMEK are largely unknown, although it is accepted that too early reduction/discontinuation of postoperative corticosteroids increases the risk [3, 5]. Interestingly, Monnereau and coworkers have demonstrated that characteristic endothelial cell changes can already be observed several months before an IR becomes clinically apparent [6], indicating that an IR may not be an acute event, but rather a slow-onset, protracted immunological response. Based on

Friederike Schaub

friederike.schaub@uk-koeln.de

1 Department of Ophthalmology, Faculty of Medicine and University Hospital Cologne, University of Cologne, Kerpener Strasse 62, 50924 Cologne, Germany

2 Center for Molecular Medicine Cologne (CMMC), University of Cologne, Cologne, Germany this, one could speculate that IRs might even be triggered by intra- or early postoperative events.

Another early, common complication after DMEK is cystoid macular edema (CME), with an incidence of about $10 \%$ [7]. Early intensified topical corticosteroids with hourly application in the first postoperative week can significantly reduce the risk for CME [8]. However, no study has so far investigated whether IR rates after DMEK can also be reduced by early intensified application of corticosteroids. Therefore, we aimed to analyze a potential protective effect of hourly corticosteroids in the first postoperative week on the incidence of IR episodes in a large DMEK cohort with a 2-year follow-up.

All eyes that underwent DMEK surgery between July 2011 and December 2018 at the Department of Ophthalmology, University of Cologne, Germany, were screened for eligibility for this retrospective interventional case series. Until the $31^{\text {st }}$ of March 2014, the first week's postoperative standard therapy in our center was prednisolone acetate $1 \%$ applied $5 \times$ daily (group 1 ). Since the $1^{\text {st }}$ of April 2014, the first week's postoperative standard therapy was changed to prednisolone acetate $1 \%$ applied hourly for 1 week (as we had shown that this regimen minimizes the risk for postoperative $\mathrm{CME}$ ), which was then tapered to $5 \times$ daily (group 
Table 1 Demographic details and descriptive analysis of patient cohorts

$\begin{array}{llc}\text { Group 1 } & \text { Group 2 } & P \text {-value } \\ \text { Prednisolone acetate eye drops } 5 \times \text { daily } & \begin{array}{l}\text { Prednisolone acetate eye drops } \\ \text { hourly for 1 week }\end{array} & \end{array}$

\begin{tabular}{|c|c|c|c|}
\hline $\operatorname{IR}(n ; \%)$ & $7 / 223(3.1 \%)$ & $12 / 826(1.4 \%)$ & $P=0.088^{\#}$ \\
\hline $\begin{array}{l}\text { Age (years; mean } \pm \mathrm{SD} \text {; range) } \\
\text { thereof with IR }\end{array}$ & $\begin{array}{l}68.1 \pm 10.7(\text { range } 39-89) \\
69.4 \pm 11.2(\text { range } 54-85)\end{array}$ & $\begin{array}{l}68.4 \pm 10.5(\text { range } 17-96) \\
67.1 \pm 7.7(\text { range } 55-76)\end{array}$ & $\begin{array}{l}P=0.681^{\#} \\
P=0.636^{\#}\end{array}$ \\
\hline $\begin{array}{l}\text { Gender } \\
(n=\text { female; } \%) \\
\text { Thereof with IR }\end{array}$ & $\begin{array}{l}\text { Female: } n=117 ; 52.5 \% \\
\text { Female: } n=3 ; 42.9 \%\end{array}$ & $\begin{array}{l}\text { Female: } n=527 ; 62.9 \% \\
\text { Female: } n=7 ; 58.3 \%\end{array}$ & $\begin{array}{l}P=0.005^{\S} \\
P=0.526^{\S}\end{array}$ \\
\hline $\begin{array}{l}\text { Mean time from DMEK surgery to IR } \\
\text { (months; mean } \pm \mathrm{SD} \text {; range) }\end{array}$ & $14.1 \pm 8.2(1-22)$ & $7.3 \pm 5.6(2-23)$ & $P=0.043^{\#}$ \\
\hline $\begin{array}{l}\text { Symptoms at timepoint if IR* } \\
(n=\text { yes; } \%)\end{array}$ & Symptoms: 2 (28.6\%) & Symptoms: $6(50.0 \%)$ & $P=0.374^{\S}$ \\
\hline $\begin{array}{l}\text { Local application of corticosteroids at } \\
\text { timepoint of IR/until IR (yes; \%) }\end{array}$ & $2(28.6 \%)$ & $8(66.7 \%)$ & $P=0.118^{\S}$ \\
\hline
\end{tabular}

Details for both patient cohorts. Mean and standard deviation (SD) or percentages (\%) are given for different variables

*Symptoms included decrease of visual acuity, corneal edema, decrease of endothelial cell density

Statistical test: ${ }^{\#} t$-test, ${ }^{\S}$ Mann-Whitney test

2). In both groups, corticosteroids were further tapered by $1 \mathrm{drop} / \mathrm{month}$, with 1 drop/day continued for at least 1 year.

Only eyes with at least 24 months of follow-up were included, and IR episodes in the first 24 months were recorded. Repeated DMEK cases were excluded. The study was approved by the local Institutional Review Board (14-373). Data were analyzed by SPSS (version 26.0 for Windows; SPSS, Inc, Chicago, IL). For statistical significance testing, Student's $t$-test was applied for interval scale parameters and Mann-Whitney test for nonparametric parameters. Association between gender and rejection was analyzed by Fisher exact test.

A total of 2413 DMEKs were performed during the study period, thereof 168 repeat-DMEKs and 1184 cases were excluded due to missing 2-year follow-up data.

Nineteen of 1061 included eyes $(60.7 \%$ female; mean age $68.4 \pm 7.3$ years) developed an IR $(1.8 \%)$. There was no significant difference between incidence of IR in male and female patients $(p=0.485)$. Mean time point of onset of IR was $9.8 \pm 13.4$ months after DMEK. After treatment, none of these eyes required a re-graft during the 2-year follow-up.

In group 1 ( $n=223$ eyes), 7 eyes $(3.1 \%)$ developed an IR episode in the first two postsurgical years, whereas in group 2 ( $n=826$ eyes) 12 eyes developed an IR (1.4\%). Although there was a trend towards less IRs in group 2, the difference was statistically not significant $(p=0.088)$. Details for both patient cohorts are given in Table 1.

Thus, our results indicate that intensified topical corticosteroids in the first postoperative week may have a positive influence on the IR rate after DMEK, as the relative number of IRs in our cohort could be halved. Nevertheless, the reduction was statistically not significant, potentially due to the already very low rate of IRs after DMEK. The potential advantages of intensified (hourly) postoperative corticosteroids might be more evident in a larger cohort with longer follow-up. Additionally, a prospective randomized study would be desirable.

Funding Open Access funding enabled and organized by Projekt DEAL. German Research Foundation (DFG) FOR2240 “(Lymph)angiogenesis and Cellular Immunity in Inflammatory Diseases of the Eye" (CC, DH www.for2240.de); EU COST BM1302 (CC, DH); EU Horizon 2020 ARREST BLINDNESS (CC).

\section{Declarations}

Conflict of interest The authors declare no competing interests.

Ethics approval All the procedures performed in studies involving human participants were in accordance with the ethical standards of the institutional research committee and with the 1964 Helsinki declaration and its later amendments or comparable ethical standards.

Informed consent For this type of study, formal consent is not required.

Open Access This article is licensed under a Creative Commons Attribution 4.0 International License, which permits use, sharing, adaptation, distribution and reproduction in any medium or format, as long as you give appropriate credit to the original author(s) and the source, provide a link to the Creative Commons licence, and indicate if changes were made. The images or other third party material in this article are included in the article's Creative Commons licence, unless indicated otherwise in a credit line to the material. If material is not included in the article's Creative Commons licence and your intended use is not permitted by statutory regulation or exceeds the permitted use, you will need to obtain permission directly from the copyright holder. To view a copy of this licence, visit http://creativecommons.org/licenses/by/4.0/. 


\section{References}

1. Anshu A, Price MO, Price FW Jr (2012) Risk of corneal transplant rejection significantly reduced with Descemet's membrane endothelial keratoplasty. Ophthalmology 119:536-540

2. Hos D, Matthaei M, Bock F et al (2019) Immune reactions after modern lamellar (DALK, DSAEK, DMEK) versus conventional penetrating corneal transplantation. Prog Retin Eye Res 73:100768

3. Hos D, Tuac O, Schaub F et al (2017) Incidence and clinical course of immune reactions after Descemet membrane endothelial keratoplasty - retrospective analysis of 1000 consecutive eyes. Ophthalmology 124(4):512-518

4. Schaub F, Bachmann BO, Cursiefen C et al (2019) Midterm follow-up of immune reactions after Descemet membrane endothelial keratoplasty (DMEK). Graefes Arch Clin Exp Ophthalmol 257(8):1811-18125

5. Price MO, Scanameo A, Feng MT et al (2016) Descemet's membrane endothelial keratoplasty: risk of immunologic rejection episodes after discontinuing topical corticosteroids. Ophthalmology 123:1232-1236

6. Monnereau C, Bruinsma M, Ham L et al (2014) Endothelial cell changes as an indicator for upcoming allograft rejection following descemet membrane endothelial keratoplasty Am. J Ophthalmol 158:485-495

7. Heinzelmann S, Maier P, Bohringer D et al (2015) Cystoid macular oedema following Descemet membrane endothelial keratoplasty. Br J Ophthalmol 99:98-102

8. Hoerster R, Stanzel TP, Bachmann BO et al (2016) Intensified topical steroids as prophylaxis for macular edema after posterior lamellar keratoplasty combined with cataract surgery. Am J Ophthalmol 163:174-179.e2

Publisher's note Springer Nature remains neutral with regard to jurisdictional claims in published maps and institutional affiliations. 